\title{
Humor in Historical Memory: from an Anecdote and Caricature to an Internet Meme
}

\section{Denis S. Artamonov}

Saratov State University. Saratov, Russia. Email: artamonovds[at]mail.ru

\begin{abstract}
The article is devoted to the study of the role of anecdotes, caricatures and Internet memes in the construction of historical memory. The memory of the past implies emotional content, the expression of which is often humor. The author views an anecdote as a component of oral history and a communication phenomenon of the pre-digital era, in which the representation of ideas about the past was humorous. A historical anecdote, being originally a kind of didactic historiography, has been transformed into a tool for transmitting an informal interpretation of history, and once in the digital media environment, it has lost its former meaning. Mass media, with the help of a caricature representing history in a humorous way, have visualized the images of the past, setting certain evaluative frameworks of historical and political events. Being an element of traditional media as well as a work of art, caricature encouraged the formation of historical memory along with other artistic genres. In the digital age, it, like a historical anecdote, has given way to Internet memes in the media sphere. The author considers Internet memes to be the phenomena of digital culture, defining them as a kind of a polymodal, metaphorical, often ironic, humorous utterance that is spread in the media environment. A historical Internet meme, combining the images of popular culture and collective memory in a visual text format, has a decisive influence on the perception of historical events and personalities by social media audiences. With the help of Internet memes a great number of Internet users create their own versions of the interpretation of history in a humorous form, thus reproducing the collectively shared mythologized ideas about the past.
\end{abstract}

Keywords

Anecdote; Caricature; Internet Meme; Humor; Humor in the Media; Historical Memory; Cultural Memory; Images of the Past; Historical Myth; Digital Culture 


\section{Юмор в исторической памяти: от анекдота и карикатуры к интернет-мему}

\section{Артамонов Денис Сергеевич}

Саратовский национальный исследовательский государственный университет имени Н. Г. Чернышевского. Саратов, Россия. Email: artamonovds[at]mail.ru

\section{Аннотация}

Статья посвящается исследованию роли анекдотов, карикатур и интернет-мемов в конструировании исторической памяти. Память о прошлом предполагает эмоциональное содержание, выразителем которого часто выступает юмор. Автор рассматривает анекдот как элемент устной истории и коммуникационный феномен доцифровой эпохи, в котором репрезентация представлений о прошлом носила юмористический характер. Исторический анекдот, будучи изначально разновидностью историографии дидактического свойства, трансформировался в инструмент трансляции неформальной интерпретации истории, а попав в цифровую медиасреду, потерял свое прежнее значение. Средства массовой информации при помощи карикатуры, репрезентирующей историю в юмористическом ключе, осуществляли визуализацию образов прошлого, задавая определённые оценочные рамки исторических и политических событий. Карикатура как элемент традиционных медиа и произведение искусства обеспечивала, наряду с другими художественными жанрами, формирование исторической памяти. В цифровую эпоху она, как и исторический анекдот, уступила свое место в медиасфере интернет-мемам. Автор относит интернет-мемы к феноменам цифровой культуры, определяя их как разновидность полимодального, иносказательного, чаще всего ироничного, шутливого высказывания, распространяющегося в медиасреде. Исторический интернет-мем, соединяя в визуально-текстовом формате образы популярной культуры и коллективной памяти, оказывает определяющее влияние на восприятие исторических событий и личностей аудиториями социальных медиа. Массы интернет-пользователей в юмористической форме с помощью интернет-мемов создают свои версии интерпретации истории, воспроизводя коллективно разделяемые мифологизированные представления о прошлом.

\section{Ключевые слова}

анекдот; карикатура; интернет-мем; юмор; юмор в медиа; историческая память; культурная память; образы прошлого; исторический миф; медиасреда

Это произведение доступно по лицензии Creative Commons «Attribution» («Атрибуция») 4.0 Всемирная 
Galactica Media: Journal of Media Studies. 2021. No 3 | ISSN: 2658-7734

From Caricature to Internet Meme | https://doi.org/10.46539/gmd.v3i3.181

\section{Введение}

Процесс конструирования исторической памяти предполагает эмоциональное отношение к образам прошлого. Роль эмоций в формировании исторических представлений вполне очевидна, если мы посмотрим на практики коммеморации. Коммеморативный акт всегда сопровождается всплеском позитивных или негативных эмоций по поводу не только самого факта увековечения какого-либо имени или события, а вскрывает весь спектр их оценок, сложившихся в исторической памяти. Эти оценки не всегда укладываются в дихотомию добра и зла, прошлое вызывает гораздо больше эмоций, не вмещающийся в бинарную оппозицию «хорошее/плохое». Жаркие споры об исторических фактах, разворачивающиеся в научной литературе, на страницах газет и журналов, в социальных медиа и выливающиеся в массовые движения в защиту или против какого-либо символического объекта прошлого, показывают, что историческая память имеет глубокое эмоциональное насыщение.

Как отметила О. Ю. Малинова: «Логика «вспоминания» и «забвения» учитывает не только «правду» исторических фактов, но и связанные с ними эмоции» (Малинова, 2010, с. 302). Исторический факт вызывает эмоции в момент своего возникновения и в результате его осмысления как события прошлого. В дальнейшем они переходят в историческую память или меняются на противоположные. Эмоциональное сопровождение установки и сноса памятников, наблюдаемое в России, странах СНГ и США в последнее время, яркое тому подтверждение. П. Нора считал, что эмоциональность никогда полностью не исчезает из «мест памяти», она может ощущаться наполовину, но всегда присутствует в их символической жизни (Нора, 1999, с. 27). По мнению исследователей Т. Энсинк и К. Соэр, для того чтобы событие подверглось забвению, необходимо забыть чувства, которое оно вызывало. Ненависть, ресентимент, вина, триумф или реванш наполняют индивидуальную или коллективную память сильными эмоциями и не оставляют места для других тем памяти. Они забываются, когда событие перестает быть актуальным, либо если «в настоящее время более не представляются полезными» (Ensink, Sauer, 2003, p. 7). Соответственно для того, чтобы событие вспомнили, оно должно вызывать сильные чувства, актуализированные повесткой дня. Механизмы формирования исторической памяти необходимым образом включают в себя эмоции, переживаемые на уровне сообществ.

Любая проводимая политика памяти эксплуатирует эмоциональное состояние общества с целью утверждения тех образов прошлого, которые соответствуют ее целям. Она работает с упрощенными нарративами, которые сводят сложные исторические процессы к удобным для восприятия схемам, мифологизируя прошедшую реальность. Мифы и коммеморативные практики, такие как ритуалы, памятные речи, публичные напоминания в виде культурного события, оказывают сильное воздействие на общество, конструируя исто- 
рическую память. Я. Ассман считал, что «представления коллективной памяти стоят в жизненной связи с формами коммуникации соответствующей группы, и эта связь несет эмоциональную и ценностную нагрузку» (Ассман, 2004, с. 41). Эффективность коммуникации внутри сообществ и между ними, направленной на репрезентацию образов прошлого, напрямую зависит от степени эмоционального накала, чем он выше, тем быстрее происходит усвоение распространяемых мифологизированных схем исторической памяти.

Травмирующее воздействие исторического события на коллективную память, по мнению Дж. Александера, напрямую связано с негативной экспансивной реакцией на него (Александер, 2012, сс. 10, 19). Роль негативных эмоций в формировании коллективных представлений о прошлом была исследована А. Ассман, использовавшей термин «эмоциональная память». По ее мнению, скорбь и вина стали главными чувствами, определяющими современное отношение к прошлому: «возрастающий интерес к истории, - пишет она, - сопровождается новым эмоциональным насыщением истории, которым более присущи горести, нежели радости» (Ассман, 2014, с. 176). Между тем, положительные чувства, как и позитивное отношение к прошлому являются фактом, который нельзя игнорировать. История обладает ценностью в современном обществе во многом потому, что положительно эмоционально нагружена.

\section{Юмор в исторической памяти}

Наблюдаемый сегодня мемориальный бум связан не только с увеличением количества исследований в области memory studies и повышенным вниманием государства к исторической памяти, наоборот, это своего рода ответная реакция на повышение общественного внимания к прошлому. Общество перестало быть только потребителем исторической информации, оно активно включено в процессы производства исторического знания через деятельность в формате публичной истории (Давыдов, 2020), реализацию проектов гражданской науки и создание исторического контента как средства развлечения (Артамонов, Тихонова, 2020). В ходе этой деятельности историческое знание теряет свою объективность и сливается с исторической памятью, растворяясь в эмоциональном восприятии масс. В массовом сознании нет четкого различения Истории на научное знание и коллективно разделяемые представления о прошлом, так как любая историческая информация подвергается личностной интерпретации с глубокой эмоциональной привязкой. Одним из важных средств выражения этих эмоций становится юмор.

Юмор как интеллектуальная способность подмечать в явлениях их комичные, смешные стороны играет значительную роль в репрезентации представлений о прошлом. Юмористическое восприятие событий обыденное явление общественной жизни, которое неоднократно становилось предметом внимания исследователей. С. Р. Шмидт, сравнивая юмористические и неюмористические варианты предложений, показал, что лучше запоми- 
наются тексты, содержащие юмор в субъективном восприятии (Schmidt, 1994), его выводы подтверждают и российские ученые (Шайхутдинова \& Кравченко, 2017). К. Карлсон, проведя анализ восприятия семантической составляющей фотографий, ключевых слов и фраз, пришел к выводу, что чаще вспоминаются образы, включающие юмористические материалы (Carlson, 2011). Эти эмпирические исследования свидетельствуют о том, что люди лучше запоминают, когда воспринимают слово, фразу или изображение как юмористические.

Изучение истории не могло обойти вниманием такую важную тему как юмор. Исследованию историко-культурных проявлений юмора посвящены работы М. М. Бахтина, который считал, что смеховая культура, проявляющаяся в живой народной речи, служит средством восстановления-обновления накопленной коллективной памяти в ее полном смысловом объеме. В шутках, гротеске, ругательствах, по его мнению, «дремлет смутная память о былых карнавальных вольностях и карнавальной правде», через юмор «память возвращается к началу и обновляет его», т. е. актуализирует прошлое в массовом сознании (Бахтин, 1990, сс. 35, 55, 533). В юмористических произведениях разного жанра прошлое сворачивается в символические фигуры с прикреплёнными к ним воспоминаниями, которые сохраняются в коллективной памяти в формате культурного кода.

В. Я. Пропп утверждал, что изучение смеха позволит установить, что связь между образами прошлого «есть не случайная связь, а что эта связь - явление, обусловленное исторически» (Пропп, 1997, с. 103), поэтому юмор можно рассматривать как ключ к культурным кодам и чувствам прошлого. Произведения юмористического жанра, как полагал исследователь интеллигентского фольклора России XX в. Ю. Б. Борев, могут объяснить белые пятна истории, показать не подвергнувшееся цензуре и идеологической мифологизации самосознание народа (Борев, 1996, с. 6), а также вскрыть духовную атмосферу того или иного исторического периода.

Исследования истории юмора Д. С. Лихачева (1984), А. М. Панченко (1984), Ю. М. Лотмана (2002) показывают, что смех представляет собой не просто феномен повседневной обыденности, а является способом конструирования социальной реальности. Смех выстраивает своего рода антимир, одновременно создавая и разрушая мир настоящего. Высмеивая, обнажая и обличая все плохое, он создает новую действительность, в которой негативные явления общественной жизни получают положительную эмоциональную окраску. Смех выполняет функцию социальной коррекции, однако, он не исправляет общественную ситуацию, а служит инструментом изменения отношения к ней. Посредством смеха и языковой игры происходит смягчение социального давления. Осмеянное зло порождает комическое, благодаря смеху ужасное сублимируется и обволакивается возвышенным.

М. Велерт, исследуя отчеты нацистского гестапо и службы безопасности $\mathrm{CC}$, выявила, что хотя политические шутки можно рассматривать как отражение меняющегося общественного мнения в нацистской Германии, 
они не были демонстрацией неприятия режима (Wöhlert, 1995). Выводы М. Велерт были развиты Р. Херцогом, исследовавшим анекдоты времен нацистской Германии. По его мнению, они убедительно доказывают, что рядовые немецкие граждане не только знали и боялись, но и поддерживали нацистские преступления, например, такие как создание и содержание концентрационных лагерей (Herzog, 2011). А Б. Адамс, проанализировав большую коллекцию советских анекдотов, пришел к убеждению, что они, конечно же, высмеивали официальные практики, были скрытой формой дискурсивного общения и способом самоутверждения, критиковали существующую реальность, но они не противостояли советской действительности, наоборот, их можно рассматривать как некую обывательскую форму согласия с социалистическим мироустройством (Bruce, 2005). Смех не столько демонстрация негативного отношения к определенным событиям, сколько инструмент изживания отрицательных эмоций, призванный при помощи юмора, т. е. интеллектуальных усилий по созданию комического эффекта, изменить восприятие действительности.

Юмор позволяет исследовать альтернативы современной реальности и раскрывать истины, которые замалчиваются или сознательно игнорируются правительством и средствами массовой информации. Борьба за власть, угнетение, насилие, несправедливость выраженные средствами юмора и сатиры показывают не реальное отношение общества к этим явлением, а то какими их хотят видеть - смешными и неопасными для рядового обывателя. Юмористические жанры не только критикуют политические события и деятелей, но и сохраняют их в сложном культурном формате в краткосрочной повседневной коммуникативной памяти и переводят сложившиеся образы в долговременную коллективную память (Twark, 2017, p. 176). Юмор наполняет историческую память ярким эмоциональным содержанием через комментирование и интерпретацию события прошлого. Юмористическая составляющая исторической памяти представляет собой контркультурные воспоминания, противостоящие официальным или общепринятым нарративам, так же как юмористическое комментирования политического события в настоящем является альтернативой насаждаемого властью образа реального мира. Официальная политика памяти государства почти всегда чужда юмору, а редкие его проявления только подтверждают это правило, поэтому юмор можно рассматривать как политику памяти общества, которая хотя и противостоит власти, одновременно становится способом ее объяснения и принятия.

\section{Исторический анекдот}

В качестве смеховой формы осмысления исторической реальности и способа конструирования представлений о прошлом может рассматриваться исторический анекдот. Изначально под анекдотом понималась поучительная 
история об общеизвестном событии и часто включающая в себя рассказ об известной личности. Анекдотам, как правило, была присуща ирония, глубокий смысл, для понимания которых требовалось знание не только действующих лиц, но и подоплеки той или иной ситуации. В анекдоте не всегда было заметно присутствие юмора, но драма или трагедия, имеющие дидактическую направленность, являются неотъемлемой его характеристикой. Материалом для создания анекдотов служили факты прошлого, которые становились содержанием исторической памяти.

Анекдот XVIII - XIX столетий был формой исторического повествования и серьезным произведением. Получив в современных исследованиях название «исторический анекдот», он представлял собой род историографии близкой античной риторике, рассказ об удивительном поступке или остроумном ответе. Исторический анекдот не был абсолютным юмористическим вымыслом, несмотря на то что вымышленные элементы там, безусловно, присутствовали, он имел под собой реальную основу. Вымышленные элементы и сюжетные изменения анекдотов были обусловлены фольклорным способом его распространения. Анекдот был частью устной истории, поэтому он постоянно видоизменялся в процессе бесконечных пересказов. Короткая форма анекдота не позволяла подробно доносить историю слушателям, события, личности, феномены вырывались из исторической канвы и вбрасывались в современный рассказчику и слушателям контекст. Однако, это не приводило к обрывочности повествования, слушателям предлагался готовый поучительный сюжет на историческую тему, с элементами мифологизированного мировоззрения, который укладывал им в головы понятные представления о прошедших временах. В. А. Кошелев справедливо отмечал, что в основе исторического анекдота лежит социокультурный миф. Причина долговечности и массового распространения анекдотов кроется в мифологической основе, с помощью которой реальные факты биографии великий личностей или происходивших событий дополняются яркими деталями, психологически точно соотнесенными с представлениями о прошлом (Кошелев, 1989, с. 36). Тем самым, анекдот был эффективным инструментом конструирования исторической памяти, он был непосредственно связан с фольклором и массовым сознанием.

Исторические анекдоты не придумывали, в их основе лежали устные рассказы очевидцев событий и участников деяний исторических личностей. Французский писатель XVII в. Таллеман де Рео в форме анекдотов запечатлел характеры Генриха IV и Людовика XIII (Петрышева, 2008). До нас дошло большое количество анекдотов о Петре I (Мезин, 2002), Екатерине II (Верещацкая, 2019), Павле I (Демичев, 2017), записанных не только литераторами, но и мемуаристами, упаковавшими свои воспоминания в формат занимательных повествований. Являясь историческим источником, они интересны и как факт устной истории, и как феномен исторического сознания. 
В начале XIX в. анекдот начал эволюцию в сторону литературного жанра и не порывая с историей стал особым видом искусства. В пушкинскую эпоху исторический анекдот существовал в формате «невыдуманных историй», «исторических портретов», «истинных происшествий», содержанием которых выступало поучение, выражение добродетели или выявление порока, но чаще всего это был рассказ о любопытном случае из прошедших эпох. Анекдоты об исторических личностях записывал А. С. Пушкин, Н. В. Гоголь придумывал рассказы анекдотичного содержания, А. М. Островский «коллекционировал» фольклорные анекдоты, Н. С. Лесков использовал анекдотичную форму для своих рассказов, А. И. Герцен собирал и публиковал анекдоты, видя в них «тайную», но истинную историю (Еремеев, 1986а; Баранова, 2011; Еремеев, 2012b).

В XX в. исторический анекдот как жанр литературы продолжает сохраняться в творчестве А. Платонова (Курганов, 1997, с. 230-236), С. Довлатова (Доброзракова, 2019) и др., но своего расцвета он достигает в советскую эпоху в качестве фольклорного произведения. В двадцатом столетии анекдот приобрел новые черты по сравнению с XVIII-XIX вв., он стал более массовым, чему способствовала ликвидация неграмотности и втягивание большого количества населения в общественно-политическую жизнь, а также расширилась тематика, охватившая практически все сферы человеческой деятельности. Можно выделить бытовые, национальные, политические, социальные и исторические анекдоты. Они становятся более краткими с концовкой, предполагающей неожиданное смысловое разрешение, которое должно вызывать смех. Анекдот использовался как инструмент коммуникации, позволяя передавать сообщения, выражающие отношение к событиям или явлениям эпохи. Советский анекдот был сетевой формой распространения информации задолго до появления социальных медиа. Его особенностью было эмоциональное насыщение рассказа об известном факте в формате короткой шутки, которая повторялась разными людьми в разных контекстах.

Особый характер анекдоты приобрели в позднесоветский период, когда они стали массовыми, были неотъемлемой частью повседневных разговоров и представляли собой альтернативу официальной политики памяти советского государства. В конце 1960-х гг. в СССР появилась целая серия анекдотов про Василия Чапаева, возникшая в контексте подготовки празднования 50-летия Великой Октябрьской Социалистической революции в 1967 г. и 100летия В. И. Ленина в 1970 г. В начале 1980-х гг. появляются анекдоты о И. В. Сталине и Л. И. Брежневе, которые стали частью коллективных неформальных ритуалов, вроде праздничных застолий, и повседневной практики, вроде разговоров в «курилках» (курительных комнатах). В постсоветские 1990-е гг. массовое хождение получили анекдоты про М. С. Горбачева, в то же время шуток про Б. Н. Ельцина практически не было, хотя в целом наблюдался повышенный интерес к анекдотам, которые стали издаваться в виде сборников огромными тиражами (Yurchak, 2005, pp. 273-276). Анекдот выполнял коммуни- 
кативную функцию по передаче представлений о прошлом между поколениями, поэтому для него было более интересно недавнее прошлое, а политическая составляющая истории экстраполировалась на современную повестку дня.

Советский исторический анекдот перестал носить дидактический характер, а имел развлекательную, юмористическую, направленность. С появлением социальных медиа, которые изменили способы коммуникации в современном мире, анекдот как жанр устного творчества сдал свои позиции. Общение в социальных сетях меняет практику рассказывания анекдотов, переводя его из разговорного жанра в текстовую и графическую форму. Краткость анекдота все же оказалась слишком громоздкой для коммуникации интернетформатов, чтобы использоваться для быстрой передачи эмоционально окрашенной информации. Анекдоты, в том числе и исторические, были записаны, оцифрованы и забыты массовым интернет-пользователем в бесконечной Сети, изредка бывая востребованными, вырываясь из небытия в сильно трансформировавшихся форматах, одним из которых стал интернет-мем.

\section{Историческая карикатура}

Несмотря на широкую распространенность устных шуток и анекдотов следует признать, что более влиятельными форматами создания общественного мнения и конструирования представлений о прошлом были и остаются медиа. Книги, театр, кинематограф и газеты, транслирующие образы прошлого, всегда имели важнейшее значения для формирования коллективной памяти, влияя на массовое сознание (Kessel, Merziger, 2012). Эффективность в воздействии на представления о прошлом данных средств массовой коммуникации объясняется возможностями визуализации истории, которыми они располагают. Визуальные образы прошлого, тиражируемые медиа, определяют восприятие исторических событий и личностей, так как представляют собой готовые и яркие картины, легко укладывающиеся в мировозренческие установки человека, во многом также сформированные средствами массовой информации.

С момента появления в СМИ возможности печатания иллюстраций, расцветает особый жанр изобразительного искусства - карикатура, использующая не только визуализацию для донесения информации до аудитории, но и юмор. Беря свое начало в средневековых гравюрах, книжных иллюстрациях, печатных листках и афишах Нового времени, лубке, карикатура представляет собой тип сатирического изображения, использующая комический эффект в визуализации информационных сообщений о социальных, политических, бытовых явлениях или людях. Как правило, она создается и распространяется в виде иллюстраций периодических изданий, газет, журналов, альманахов и др., листовок, лубочных картинок, литографий, сатирических открыток, т. е. существует во всех видах прикладной тиражной графики. Особенностью 
карикатурных изображений является их сопровождение текстовым комментарием, который расширяет возможности понимания и интерпретации визуального сообщения [Барт, 2003, pp. 378-392], но рисунок может обходится без него, что не влияет на цели карикатуры - сознательное преувеличение, заострение, высмеивание чего-либо или кого-либо.

Сатирическая карикатура несёт в себе отклик художника и редакции периодического издания на определённые события или явления, в которой сохраняется драматургия конкретных фактов. Иногда карикатура из сатирического отклика превращается в обыкновенную констатацию тех или иных сюжетов, но с обязательным применением комической составляющей рисунка. Граница между вымыслом и фактом в карикатуре тонко прочерчивается художником с тем, чтобы снабдить аудиторию информацией к размышлению, почему тот или иной человек, ситуация стали предметом внимания и осмеяния. Поэтому карикатура может быть очень точным историческим источником, рассказывающем не только о событии, но и отношении к нему со стороны политических сил и социальных слоев, интересы которых представляют ее создатели: автор и редакция СМИ.

Исторические события и личности неоднократно становились предметом изображения карикатуристов. Чаще всего это происходило, когда исторические факты оказывались в повестке дня в связи с политической актуализацией прошлого. В этом отношении карикатура была, с одной стороны, выражением определенных представлений о истории, обусловленных мировозренческими установками, стереотипами, мифами или политической позицией, а с другой, она создавала образы прошлого и помещала их в коллективную память, т. е. работала точно так же как и любой инструмент медиа.

Вместе с тем, роль художника-карикатуриста в трансляции образов прошлого заключалась в том, что он, выражая свои исторические взгляды, опирался во многом на штампы популярной культуры и представления масс. Как показал Р. Дуглас, автор исследований по истории европейской карикатуры второй половины XIX-го и первой половины XX-го вв., сатирические рисунки являются более точным указателем народных чувств, чем газеты, в которых они появлялись (Douglas, 1992; Douglas, 1993). Карикатура на историческую тему использовалась как зеркало современности, поэтому она хорошо показывает, как визуальные образы, транслируемые средствами массовой информации, и массовые представления о прошлом соотносились с национальной политикой в решающие периоды новейшей истории.

Через карикатуры с большей степенью эффективности навязывались образы, мифы и стереотипы, оказывающие влияние на восприятие исторических событий и личностей. Их характерной особенностью является применение принципа повторяемости и узнаваемости определенных элементов изображения, таких как символы страны, национальная одежда, ландшафт, черты внешности, отличительные атрибуты политической личности (усы Петра I, трубка И. Сталина, сигара У. Черчиля и др.). Условность карика- 
турных изображений позволяет читателям персонифицировать образы, домысливать реальность, соотносить ее со своими историческими знаниями и мировозренческими установками. Использование визуальных образов, знаков и символов, делающих узнаваемым событие прошлого, одновременно создает сатирическую тональность, которая способствует принятию передаваемого представления о прошедшей реальности, так как переводит его в юмористическую плоскость, таким образом исторический факт запоминается и переходит в коллективную память (Башарян, 2018, с. 201).

В карикатурах часто используются намеки или аллюзия на историческое событие, исторический или литературный факт, предполагающийся общеизвестным, подкреплённые для достижения комического эффекта каламбуром, ононимией, «двойным толкованием». Тем самым, образы прошлого переводятся в разряд смешного и закрепляются в коллективной памяти. В период Отечественной войны 1812 г. в журнале «Сын Отечества», где редакция не столько собирала новости, сколько сочиняла их, так как долго не удавалось наладить систему корреспонденций, карикатуры, как и все другие материалы, призваны были восполнить недостаток военных сведений. Публицисты и карикатуристы использовали в своем творчестве аллюзии из античной и европейской истории, а также небольшое число метафор, намекающих на русский характер и национальные традиции (Вишленкова, 2012). Хрестоматийный пример данного факта - карикатура И. И. Теребенева «Русский Сцевола», изобразившая реальный подвиг русского крестьянина, отрубившего себе руку на глазах французских солдат, переданная с явно читаемыми аллюзиями на римскую историю. В исследовании М. В. Мисийчук, посвященном анализу карикатур журнала «Крокодил» периода Великой Отечественной войны, показано, как в сатирических рисунках, изображающих борьбу советского народа с нацистской агрессией, использовались узнаваемые исторические и литературные образы Древней Руси, Запорожской Сечи, А. С. Пушкина, И. А. Крылова, Ш. Руставели и др. (Мусийчук, 2020).

Карикатура, являясь неотъемлемой частью средств массовой информации, представляет факты прошлого обществу, переводя их в яркие визуальные образы с юмористической составляющей. Она делает сложные исторические процессы понятными рядовому обывателю, а деятелей истории узнаваемыми и запоминающимися. Сегодня карикатурный жанр является самостоятельным видом графического искусства, потерявшим свое было значение в сфере медиа. Карикатурные изображения продукт индивидуального творчества, требующего интеллектуальных усилий, художественного таланта и профессионализации. Профессионалов-карикатуристов единицы, тогда как медиасфера требует массовой визуализации информации, что делает востребованными фотоиллюстрации, коллажи, графические цифровые картинки. Роль карикатур в современных медиа стали выполнять интернет-мемы, которые также способны передавать юмор в сообщениях о событиях, но более доступны для массового производства. Карикатура растворилась в медиасфере 
среди конкурирующих жанров, иногда появляясь в виде шедевров художественного творчества, в том числе, имеющего отношение к репрезентации исторической памяти, как например, в рисунке А. Некрасова, широко распространенному в сети Интернет, где Петр I рубит бороду топором хипстеру («HTB», 2018).

\section{Исторический Интернет-мем}

Анекдот и карикатура в цифровой среде трансформировались в новый коммуникационный феномен с юмористической составляющей - интернетмем, объединивший их характерные признаки: юмористичность, нарративность и визуализацию. В частных случаях, например, в области политической сатиры факультативным признаком интернет-мема может быть метафоричность, под которой в данном случае следует понимать иносказательность, полимодальность и фигуральность передаваемых образов. Также как анекдоты и карикатуры интернет-мемы, содержащие образы прошлого, оказывают большое влияние на формирование коллективной памяти, чему способствует их вирусное распространение, эмоциональная юмористическая наполненность и простота создания. Интернет-мем можно назвать одним из самых эффективных инструментов конструирования представлений о прошлом.

Термин «мем», появился благодаря Р. Докинзу, который понимал его как единицу передачи культурной информации, проводя параллели между механизмами передачи генетической информации и функционированием коллективной памяти. На основе его идей возникла дисциплина «меметика», последователи которой были склонны рассматривать любые мыслительные конструкции, символы, знаки, манеры или образы действия, распространяемые в обществе, в качестве мемов. С. Блэкмор определяла мем как пример для поведения человека, передаваемый через подражание (Blackmore, 1999), Д. Ж. Уилкинс, продолжая биологический подход Р. Докинза, считал мем «единицей культурной эволюции и отбора» (Wilkins, 1998, p. 56), Ф. Хейлинген утверждал, что мем - это информационный паттерн, который может быть скопирован из одного мозга в другой (Heylighen, 1998), Д. Деннет встроил концепт мема в теорию разума (Dennett, 1991), Р. Броуди называл мем вирусом ума (Brodie, 1996), а Д. Рашкофф медиавирусом (Rushkoff, 1996). В этих исследованиях, использовавших меметический подход к анализу социокультурных явлений, вирусная природа мемов, под которой понималось массовое воспроизводство и неконтролируемое распространение в процессе коммуникации, выводилась на передний план. Однако, меметика не выросла в полноценное научное направление, подвергнувшись критике за стремление к всеохватности, универсальности и в то же время абстрактной умозрительности как со стороны ученых гуманитарного профиля, так и со стороны представителей естественных наук, она потеряла свое концептуальной значение для исследования мемов, под которыми стали понимать забавные слова, 
крылатые выражения, фразы, шутки, картинки или видео, массово распространяющиеся в интернет-среде (Шомова, 2015, с. 31).

C 2010-х гг. мем начали рассматривать в более узком значении в качестве медиамема или интернет-мема. П. Дэвисон определял интернет-мем как часть цифровой культуры, неотъемлемым элементом которой являются шутливые сообщения, часто визуального характера, распространяемые посредством онлайн-передачи (Дэвисон, 2012, р. 122). Л. Шифман обозначала интернет-мем как «группу цифровых элементов, имеющих общие характеристики содержания, формы и/или выражаемой позиции, которые созданы с осознанием соответствия друг другу, и были распространены, имитированы и/или преобразованы через Интернет многими пользователями, формируя общий культурный опыт (Shifman, 2014, p. 41). Р. Милнер указывал, что интернет-мемы предназначены для публичных комментариев в цифровой среде (Милнер, 2013, p. 2359). А. Дайнас рассматривал их как жанр цифрового юмора и творчества (Дайнас, 2015, р. 59).

Интернет-мемы представляют собой цифровые объекты, которые имеют определенную визуальную, текстовую или аудиальную форму, состоят из образов поп-культуры, политики или повседневной жизни, которые реконструируются пользователями, присваиваются, перекодируются и помещаются обратно в инфраструктуру Интернета, из которой они пришли (Nooney \& Portwood-Stacer, 2014, p. 249) Мемы идеально сочетают в себе визуальную и языковую коммуникацию, однако, специфика цифровой культуры сделала визуализацию более важной (Johann, Bülov, 2019, p. 1723). Самым распространённым типом интернет-мема в настоящее время является мультимодальный цифровой объект, сочетающий текст и изображение. Текст, как правило, состоит из одной или двух строк текста вверху и/или нижней части интернет-мема, дополняя изображение. Изменение текста или изображения создаёт бесконечные возможности интерпретации ключевого сообщения, содержащегося в интернет-меме, и способствует его массовому тиражированию. Каналами распространения интернет-мемов являются социальные сети и приложения для обмена мобильными сообщениями, а инструментами их производства служат специализированные веб-сайты и специальные приложения для смартфонов, которые имеют возможность автоматической генерации мем-сообщений. Интернет-мемы это не только продукт массового творчества интернет-пользователей, они могут создаваться цифровыми технологиями и искусственным интеллектом, ботами. Созданные автоматически, как и придуманные человеком, интернет-мемы с равной степенью действенности могут влиять на восприятие их аудиторией. В них можно закодировать любое сообщение, а при помощи неожиданного сочетания изображения и текста или нескольких изображений между собой можно добиться комического эффекта, который возникает из-за столкновения несоответствующих друг другу элементов (Yus, 2021). Простота изготовления интернет-мемов и высокая степень влияния на аудиторию, обеспечиваемого юмористическим 
содержанием, делают их эффективным инструментом массовой коммуникации.

Интернет-мемы в цифровой среде существуют не только как средство развлечения, хотя их рекреационная функция достаточно значительна. Они возникают в качестве эмоционального отклика интернет-пользователей на события повестки дня. Материалом для создания интернет мемов чаще всего служат образы массовой культуры, но могут использоваться и образы, символизирующие прошлое. В этих случаях интернет-мем превращается в инструмент конструирования исторических представлений. В эпоху мемориальных войн и распространения исторических фейков эти случаи не редкость.

В качестве отклика на общественно-значимое событие возник интернетмем «Иван Грозный убивает». В октябре 2013 г. представители православных организаций обратились $\mathrm{c}$ открытым письмом к министру культуры В. Р. Мединскому и директору Третьяковской галереи И. В. Лебедевой с просьбой убрать картину И. Е. Репина «Иван Грозный и его сын Иван 16 ноября 1581 г.» из экспозиции, так как, по их мнению, полотно оскорбляет патриотические чувства россиян, являясь клеветой на русского царя, не убивавшего своего сына. Сообщения об этом письме в СМИ породили первую волну интернет-мемов в виде фотожаб, в которых Иван Грозный с холста И. Репина помещался на другие картины и в разные обстоятельства. Иван Грозный «убивал» «Неизвестную» И. Крамского, «Девочку с персиками» В. Серова, Марата с картины Ж.-Л. Давида, «Крик» Э. Мунка, «Черный квадрат» К. Малевича, «Упоротого лиса», «Ждуна», «R2-D2» из кинофильма «Звездные войны» и т. д. Персонаж прошлого в этих интернет-мемах совмещался с художественными образами и символами массовой культуры, в результате чего он и его история актуализировались в историческом сознании современных россиян. Иван Грозный в образе с картины И. Репина закрепился в медиасреде и стал появляться в интернет-мемах после каждого упоминания его имени в СМИ. В 2016 г. вторая волна интернет-мемов началась после сообщений об оговорке губернатора Орловской области В. Потомского, который собирался поставить памятник царю. Он сказал, что царевич Иван заболел во время путешествия с отцом из Москвы в Петербург, такого интернетпользователи пропустить не могли и откликнулись на эту новость юмористическими интерпретациями истории. Новая волна интернет-мемов появилась в начале 2017 г., когда вокруг мема разразился медийный скандал после публикации его новогодней версии в издании «Брянск Today», где царю приписаны слова: «Вставай, там еще оливье и крабовый остались, нужно докушать», а царевичу слова - «Дай мне умереть». Самая большая волна вариаций фотожаб «Иван Грозный убивает» возникла в июле того же года в ответ на слова Президента РФ В. В. Путина, который в преддверии Дня металлурга посетил Лебединский горно-обогатительный комбинат и, отвечая на вопрос о противодействии фальсификации истории, усомнился в достоверности свидетельств исторических источников об убийстве царем своего сына. 
В мае 2018 г. И. Подпорин, считавший Ивана Грозного святым, а полотно И. Репина исторически недостоверным и оскорбляющим чувства верующих, повредил его, нанеся по картине несколько ударов стойкой ограждения, это событие также широко освещалось в СМИ, что вновь привлекло внимание к артефакту и связанным с ним интернет-мемам. С их помощью пользователи социальных медиа высказывают свое отношение к спорам о достоверности картины, начавшиеся с момента ее появления на публике в конце XIX в. Они остроумно и с большой долей юмора превратили историю убийства царем Иваном IV своего сына в абсолютный фейк, совершенно неправдоподобный, что в свою очередь сбило накал страстей вокруг неоднозначного исторического сюжета.

История в современном мире стала ценным информационным ресурсом, но она востребована не как научное знание о прошлом, а как набор штампов, стереотипов, шаблонов, моделей поведения и мифов. Исторический миф в массовом сознании играет определяющую роль в формировании коллективной памяти. Л. П. Репина понимала под этим термином «представления о прошлом, воспринимаемые в данном социуме как достоверные «воспоминания» (как «история»), составляющие значимую часть картины мира и играющие важную роль как в ориентации, самоидентификации и поведении индивида, так и в формировании и поддержании коллективной идентичности и трансляции этических ценностей» (Репина, 2011, с. 453). По мнению Ю. М. Лотмана, перевод мифа в привычные формы сознания превращает его в метафору. Мифологический образ, воспринимаемый в категориях рационального сознания, порождает метафорические конструкции, через которые производится репрезентация представлений о прошлом в памяти культуры. Механизмы коллективной памяти фиксируют исключительные события, эксцессы, случаи и происшествия, которые сохраняются в ней, приобретая форму метафоры (Лотман, 2010, сс. 364, 535).

Связь между метафорой и юмором в интернет-мемах была прослежена А. Пиата. Согласно ее исследованию, юмористические интернет-мемы перестраивают метафорическую концептуализацию, связанную с ними, и порождают то, что она назвала «переработанными юмористическими метафорами», которые изначально не обязательно являются смешными, но становятся таковыми благодаря их творческому использованию и в результате взаимодействия между вербальной и визуальной модальностью (Piata, 2016, p. 54). Когда метафора, репрезентирующая представления о прошлом, становится шуткой в интернет-меме, используется ее образный потенциал, который делает узнаваемым исторический миф, а юмор способствует его встраиванию в современный дискурс.

Одним из наиболее мифологизированных периодов истории является петровская эпоха. Восприятие истории Петра I в коллективной памяти сводится к набору мифов и связанных с ним метафор: «прорубил окно в Европу», «брил бороды боярам и обрезал полы русских кафтанов», «построил 
Санкт-Петербург на болотах» и т. д. Все это нашло отражение в интернетмемах, в которых пользователи социальных медиа репрезентируют свои представления о первом российском императоре, связывая их с повесткой дня. Метафора «окно в Европу» актуализировалась в российском массовом сознании после 2014 г., когда вновь стал актуальным стереотип противостояния России западной цивилизации и ее ценностям. В это время появляется красноречивый интернет-мем с портретным изображением Петра I, созданным Полем Деларош в 1838 г., и подписью «окно в Европу срочно заколотить! Нынче вид из него ужасный!». Среди вариаций на эту тему можно отметить интернет-мем «А Нарва то русский город!!! Пора ему возвращаться!!! Хватит болтаться по европомойкам» и «Прорубил окно. Чувствую кривовато вышло!», которые, используя метафору, транслируют негативную оценку европейской цивилизации. Метафора в этих интернет-мемах, как и в большинстве подобных случаев (Piata, 2016, p. 39), задает оценочные рамки, а юмор служит средством критики. В этом отношении показателен также интернет-мем сравнивающий Петра Великого и украинского президента Петра Порошенко: «Оба Петра хотели в Европу. Один для этого поднял страну, а другой ее разрушил». В этом интернет-меме метафоричное сравнение истории и современности определяет оценку политических событий.

Популярный исторический сюжет о введении Петром I брадобрития, ставший метафорой восприятия его правления, нашел отражение в интернетмемах «Я сбрил бороды, а чего добился ты?», «Я человек простой, вижу бороду рублю с плеча», а также созданном на основе картины Н. Ге «Пётр I допрашивает царевича Алексея Петровича в Петергофе» и строчки из известной песни популярных рэп-исполнителей Doni и Тимати, где царевичу приписаны слова «У тебя есть борода? - Я скажу тебе: «Да». Если бороды нет, то и «нет»мой ответ», а императору фраза: «Ты, вообще, с головой дружишь, нет?». В этих интернет-мемах, являющихся откликом на распространение субкультуры хипстеров и творчество рэперов, комический эффект от несоответствия текста и изображения, фигуры исторического героя и приписываемых ему слов, способствует воспроизводству исторического мифа и создает новый контекст его восприятия.

Миф о строительстве Санкт-Петербурга на болотах обыгрывается в серии интернет-мемов, в которых Петр I отождествляется со Шреком, персонажем мультипликационного фильма киностудии Dreamworks Pictures. Первый интернет-мем этой серии появился 25 января 2017 в социальной сети «Вконтакте» в паблике «Деградач», он представлял собой портретное изображение Петра I, с надписью: «Осел! Нет никаких «мы», нет никакого «наше». Есть только я и мое болото! - Шрек». Цитата из широко известного мультфильма, остроумно приписанная первому русскому императору, включает исторического деятеля в контекст современной массовой культуры. Большое количество вариаций этого интернет-мема возникло уже через месяц. Интернет-пользователи из фотографии мягкой игрушки, которая висит 
на набережной и с грустью смотрит вдаль, сделали мем «Грустный Шрек» с надписью «Когда на твоем болоте построили Питер». Такими же популярными стали мемы из мультипликационных кадров, где Шрек изображен на болоте в костюме XVII в., с надписью: «Ооо, ... Вот тут и будем строить Питер! (C) Петр I», и где Шрек и Фиона показаны на фоне моря и крепости с надписью «Петр Первый и Екатерина Первая на набережной Невы. Санкт-Петербург, 1722 г. Фото в цвете». Тема строительства Северной столицы в болотистой местности нашла отражение в интернет-мемах на основе популярной фотожабы «Школьник в болоте», куда вклеили портрет Петра I и придумали подпись: «Когда нашел место, где построишь город». Также массовое хождение имел мем изображающий императора, указывающего на болото, с надписью: «Когда спрашивают, где будем строить город!» и мем со спорящими из-за принадлежности болота лягушками, в котором Петр I присваивает его себе. В результате распространения нескольких волн мемов на эту тему интернет-пользователи стали проводить прямые параллели между исторической личностью и анимационным персонажем, утверждая, что Петр I и Шрек одно и тоже лицо. В видеообзоре на YouTube-канале «Пентиумбич» с названием «Питерский Шрек: вся правда», его автор, молодой человек, «аргументировано» доказывает, что Петр I был Шреком, а в социальных сетях стал распространятся мем «Ой, из-вини, две одинаковых фото скинул», с их изображениями.

Отождествление исторических деятелей с образами массовой культуры, персонажами и предметами на подобии серии интернет-мемов «Петр I Шрек» не единственный пример такого рода. В 2010-х гг. приобрел популярность интернет-мем «Ленин-гриб», возникший благодаря републикации в сети Интернет телевизионного сюжета С. Курехина и С. Шолохова 1991 г., делавших передачу «Пятое колесо» на Ленинградском телевидении. Смысл сюжета был в мистификации, преследующей цель доказать, что при помощи телевидения можно обосновать любой миф. В данном случае авторы утверждали, что В.И. Ленин в большом количестве употреблял галлюциногенные грибы и в результате сам превратился в гриб. Современные пользователи социальных медиа взяли этот сюжет как основу для создания интернет-мема, соответствующего современной эпохе постправды, когда объективные факты перестали иметь значение, а востребованы новости, ориентированные на эмоции, личные убеждения и мировозренческие установки. Так, когда Президент РФ В. В. Путин, выступая в прямом эфире в период пандемии COVID-19, вольно процитировал исторический анекдот о знаменитом адвокате Ф. Н. Плевако, сказав про Россию, «и печенеги ее терзали, и половцы, - со всем справились. Победим и эту заразу коронавирусную», мгновенно возник интернет-мем «Главные враги России», где половцы стали пловом, печенеги - печеньками, монголы - мангалами, турки - туркой для кофе. Пытаясь проассоциировать печенегов и половцев с чем-то знакомым их мировоззрению, чтобы актуализировать в настоящем почти совсем забытые кочевые племена, сделать их понят- 
ными и узнаваемыми, интернет-пользователи не нашли никаких других соответствий, кроме фонетически близких гастрономических наименований, а ассоциации с монголами и турками образовались по тому же принципу.

Использование истории в развлекательных целях и в качестве материала для создания эмоциональных откликов на повестку дня в интернет-мемах неизбежно выглядит комично, так как исторические образы помещаются в необычные контексты, с которыми они связываются при помощи юмора. Юмористический эффект, получаемый от соединения несоединимого в интернет-мемах, определённым образом трансформирует представления о прошлом. Играя положительную роль актуализации исторических образов в современности, юмор создает новые возможности восприятия и интерпретации прошлого. Оно перестает быть чужим и далеким, а становится неотъемлемой частью общественной жизни и цифровой культуры, правда, в сильно мифологизированном виде.

\section{Выводы}

Юмористическое восприятие прошлого является неотъемлемой частью исторической культуры. В доцифровую эпоху юмористическая интерпретация истории осуществлялась при помощи анекдотов и карикатур. Анекдот изначально возник как вид историографии, а затем трансформировался в формат коротких юмористических рассказов, используемых при межличностном общении с целью передачи информации и, что самое главное, ее эмоциональной оценки. Анекдот стал неформальной формой коммуникации, распространяясь в обывательской среде как фольклорное произведение или элемент устной истории. Карикатура с момента своего возникновения существовала в медиасреде, через средства массовой информации реализуя те же цели, что и анекдот, с ее помощью транслировалась определенная эмоциональная оценка общественно-значимого события. Прикрепление эмоций, задаваемых юмористической составляющей исторического анекдота и карикатуры, к образу прошлого обеспечивало его функционирование в коллективной памяти. Анекдот и карикатура стимулировали историческое или логикопсихологическое любопытство, адаптируя историю к современности и через прошлое формируя оценку настоящего. Фактически анекдот и карикатура формы исторической памяти. С наступлением эры цифровизации и развития социальных медиа, изменивших способы коммуникации, роль анекдота и карикатуры в юмористической трансляции прошлого перешла к интернетмемам. Они выполняют те же функции, находясь одновременно в двух коммуникационных пространствах - неформального межличностного общения и медиасфере, обеспечивая связь между ними в виде эмоциональных откликов интернет-пользователей на повестку дня. Интернет-мемы создают новое качество представлений о прошлом, соответствующее эпохе постправды, превращая историю в фейк, который выступает альтернативой современной 
действительности, а также насаждаемым государственной политикой памяти и медиа историческим предствлениям. Юмор в интернет-мемах выполняет конструирующую функцию, обеспечивая эмоциональное восприятие образов прошлого, а также соединяя мифы и стереотипы массовой культуры с прошедшей реальностью, формирует пространство творческой интерпретации исторической памяти массами интернет-пользователей.

\section{Благодарности}

Исследование выполнено при финансовой поддержке РФФИ в рамках научного проекта № 20-09-42063 «Петр I в исторической памяти современной России: репрезентация образа в медиасреде»

\section{Список литературы}

Blackmore, S. (1999). The meme machine. New York: Oxford University Press.

Brodie, R. (1996). Virus of the Mind: The New Science of the Meme. Seattle; Washington: Integral Press.

Bruce, A. (2005). Tiny Revolutions in Russia: Twentieth Century Soviet and Russian History in anecdotes. New York; London: RoutledgeCurzon.

Carlson, K. A. (2011). The impact of humor on memory: Is the humor effect about humor? Humor International Journal of Humor Research, 24(1), 21-41. doi: 10.1515/humr.2011.002

Dainas, A. (2015). Keep Calm and Study Memes. Cleveland: Case Western Reserve University.

Davison, P. (2009). The Language of Internet Memes. In M. Mandiberg (Ed.), The Social Media Reader (pp. 120-136). New York; London: New York University Press.

Dennett, D. (1991). Consciousness Explained. Boston: Little, Brown a. co., Cop.

Douglas, R. (1992). Between the wars 1919-1939: The cartoonists' vision. London: Routledge.

Douglas, R. (1993). Great Nations Still Enchained: The Cartoonists' Vision of Empire 1848-1914. London: Routledge.

Ensink, T., \& Sauer, C. (Eds.). (2003). The art of commemoration fifty years after the Warsaw Uprising. Amsterdam: John Benjamins Publishing Company.

Herzog, R. (2011). Dead Funny: Telling Jokes in Hitler's Germany. Brooklyn; NY: Melville House.

Heylighen, F. (1998). What makes a meme successful? Selection criteria for cultural evolution. In J. Ramaekers (Ed.), 15th International Congress on Cybernetics (pp. 418-423). Namur: Association Internationale de Cybernetique.

Johann, M., \& Bülow, L. (2019). One Does Not Simply Create a Meme: Conditions for the Diffusion of Internet Memes. International Journal of Communication, 13, 1720-1742.

Kessel, M., \& Merziger, P. (Eds.). (2012). The Politics of Humour: Laughter, Inclusion and Exclusion in the Twentieth Century. Toronto; Buffalo; London: University of Toronto Press.

Milner, R. M. (2013). Pop Polyvocality: Internet Memes, Public Participation, and the Occupy Wall Street Movement. International Journal of Communication, 7, 2357-2390. 
Galactica Media: Journal of Media Studies. 2021. No 3 | ISSN: 2658-7734

От карикатуры до интернет-мема | https://doi.org/10.46539/gmd.v3i3.181

Nooney, L., \& Portwood-Stacer, L. (2014). One Does Not Simply: An Introduction to the Special Issue on Internet Memes. Journal of Visual Culture, 13(3), 248-252. doi: 10.1177/1470412914551351

Piata, A. (2016). When metaphor becomes a joke: Metaphor journeys from political ads to internet memes. Journal of Pragmatics, 106, 39-56. doi:10.1016/j.pragma.2016.10.003

Rushkoff, D. (1996). Media Virus!: Hidden Agendas in Popular Culture. New York: Ballantine Books.

Schmidt, S. R. (1994). Effects of humor on sentence memory. Journal of Experimental Psychology: Learning, Memory, and Cognition, 20(4), 953-967. doi: 10.1037/0278-7393.20.4.953

Shifman, L. (2014). Memes in Digital Culture. Massachusetts: MIT Press.

Twark, J. E. (2017). Approaching History as Cultural Memory Through Humour, Satire, Comics and Graphic Novels. Contemporary European History, 26(1), 175-187. doi: 10.1017/ S0960777316000345

Wilkins, J. S. (1998). What's in a meme? Journal of Memetics - Evolutionary Models of Information Transmission, 2(1), 56-94.

Wöhlert, M. (1995). Der politische Witz in der NS-Zeit am Beispiel ausgesuchter SD-Berichte und Gestapo-Akten [The political joke in the Nazi era using the example of selected SD reports and Gestapo files]. Berlin: Freie Universität. (In German).

Yurchak, A. (2005). Everything Was Forever, Until It Was No More: The Last Soviet Generation. Princeton; Oxford: Princeton University Press.

Yus, F. (2021). Incongruity-resolution humorous strategies in image macro memes. Internet Pragmatics, 4(1), 131-149. doi: 10.1075/ip.00058.yus

Александер, Д. (2012). Культурная травма и коллективная идентичность. Социологический журнал, (3), 5-40.

Артамонов, Д. С., \& Тихонова, С. В. (2020). «Гараж» истории: Цифровой поворот «независимых исторических исследований». Диалог Со Временем, (72), 237-254. doi: 10.21267/ AQUILO.2020.72.72.015

Ассман, А. (2014). Длинная тень прошлого: Мемориальная культура и историческая политика. Москва: Новое Литературное Обозрение.

Ассман, Я. (2004). Культурная палять. Письмо, палять о прошлом и политическая идентичность в высоких культурах древности. Москва: Языки славянской культуры.

Баранова, Н. С. (2011). Анекдот как форма изображения исторических событий и персоналий в произведениях Н.С. Лескова. Вестник Чувашского университета, (4), 291-293.

Барт, Р. (2003). Система моды. Статьи по семиотике культуры. Москва: Издательство им. Сабашниковых.

Бахтин, М. М. (1990). Франсуа Рабле и народная культура средневековья и Ренессанса. Москва: Художественная литература.

Башаран, В. И. (2018). Карикатура как исторический источник для изучения международных отношений (на примере России и Турции). Эхо Веков, (1), 192-203.

Борев, Ю. Б. (1996). ХХ век в преданиях и анекдотах (Т. 1). Харьков: Фолио.

Верещацкая, И. А. (2019). Образ Екатерины II в городском фольклоре XVIII - первой половины XIX века (на примере исторических анекдотов и слухов). Европа в Средние века и Новое время: Общество. Власть. Культура: Материалы VI Всероссийской с международным 
участием научной конференции молодых ученых, Ижевск, 04-05 декабря 2018 г., 215-220. Ижевск: Ижевский институт компьютерных исследований.

Вишленкова, Е. А. (2012). «Метки на память»: Сатирические образы войны 1812 года. История и историческая память, (6), 150-163.

Давыдов, В. А. (2020). История в публичном пространстве: Проблемы и перспективы развития. Современная наука: актуальные проблемы теории и практики. Серия: Познание, (3), 97-99.

Демичев, А. А. (2017). Образ Павла I как «идеального» монарха в российском общественном сознании XVIII - начала XIX В. (по материалам исторических анекдотов). Историкоправовые проблемы: новый ракурс, (2), 27-36.

Доброзракова, Г. А. (2019). Исторический анекдот от XVIII века до Довлатова. В Проблелы изучения русской литературы XVIII века: Межвузовский сборник научных трудов, посвящённый памяти профессора, кандидата филологических наук, Наталии Аркадъевны Буранок (сс. 38-57). Санкт-Петербург; Самара: ООО «Научно-технический центр».

Еремеев, А. Э. (1986). А. С. Пушкин и А. И. Герцен (к вопросу о художественных функциях философского обобщения в форме исторического анекдота в прозе 1830-х г.). В Проблемы метода и жанра (сс. 183-196). Томск: Национальный исследовательский Томский государственный университет.

Еремеев, А. Э. (2012). Исторический анекдот как форма художественно-философского обобщения в русской прозе первой трети XIX в. Омский научный вестник, (2), 141-146.

Кошелев, В. А. (1989). Исторические функции биографического анекдота (Пушкин и Батюшков). В Жанры словесного творчества. Анекдот (с. 30). Таллин.

Курганов, Е. (2014). Анекдот как жанр русской словесности. Москва: ArsisBooks.

Лихачев, Д. С. (1984). Смех в Древней Руси. Ленинград: Наука, Ленинградское отделение.

Лотман, Ю. М. (2002). Художественная природа русских народных картинок. В Статьи по семиотике культуры и искусства (сс. 322-339). Санкт-Петербург: Академический проект.

Лотман, Ю. М. (2010). Семиосфера. Санкт-Петребург: Искусство-СПб.

Малинова, О. Ю. (2019). Политика памяти как область символической политики. Метод, (9), 285-312.

Мезин, С. А. (2002). Анекдоты о Петре Великом как явление русской историографии XVIII века. Историографический сборник, (20), 18-54.

Мусийчук, М. В. (2020). Историческая память в рисунках и карикатурах журнала «Крокодил» (1941-1945) через призму приемов остроумия. Мир науки. Сощиология, филология, культурология, 11(1), 3-11.

Нора, П. (1999). Проблематика мест памяти. В Франция-память (сс. 17-50). Санкт-Петербург: Издательство Санкт-Петербургского университета.

Панченко, А. М. (1984). Русская культура в канун петровских реформ. Ленинград: Наука, Ленинградское отделение.

Петрышева, О. В. (2008). Занимательные истории Таллемана де Рео: Традиция и новаторство. Известия Российского государственного педагогического университета им. А.И. Герцена, (73-1), 347-351. 
Пропп, В. Я. (1997). Проблемы комизма и смеха. Санкт-Петербург: Алетейя.

Репина, Л. П. (2011). Историческая наука на рубеже XX-XXI вв.: Социальные теории и историографическая практика. Москва: Кругъ.

Художник решил судиться с шоколадной фабрикой из-за рисунка на фантике. (2018). Извлечено от HTB website: https://www.ntv.ru/novosti/1972378/?fb

Шайхутдинова, 3. И., \& Кравченко, Ю. Е. (2017). Как влияет тематическая связь юмора и запоминаемого образа на репрезентацию образа в памяти? В Е. В. Печенкова \& М. В. Фаликман (Ред.), Когнитивная наука в Москве: Новые исследования. Материалы конференции, Москва, 15 июня 2017 г. (сс. 403-406). Москва: КТ «Буки-Веди», Институт практической психологии и психоанализа.

Шомова, С. (2019). Выборы президента РФ - 2018 в зеркале мемов: Новые реалии политической коммуникативистики. Полис. Политические исследования, (3), 157-173. doi: 10.17976/jpps/ 2019.03.10

\section{References}

Alexander, D. (2012). Cultural trauma and collective identity. The Sociological Journal, (3), 5-40. (In Russian).

Artamonov, D. S., \& Tikhonova, S. V. (2020). The "garage" of history: the digital turn of "independent historical research". Dialogue with Time, (72), 237-254. doi: 10.21267/AQUILO.2020.72.72.015 (In Russian).

Assman, A. (2014). The Long Shadow of the Past: Memorial culture and Historical Politics. Moscow: New Literary Review. (In Russian).

Assman, Ya. (2004). Cultural memory: Writing, memory of the past and political identity in the high cultures of antiquity. Moscow: Languages of Slavic culture. (In Russian).

Bakhtin, M. M. (1990). Rabelais and His World. Moscow: Fiction. (In Russian).

Baranova, N. S. (2011). Anecdote as a form of representation of historical events and personalities in the works of N. S. Leskov. Bulletin of the Chuvash University, (4), 291-293. (In Russian).

Barth, R. (2003). The fashion system. Articles on the semiotics of culture. Moscow: Sabashnikov Publishers. (In Russian).

Basharan, V. I. (2018). Caricature as a historical source for the study of international relations (on the example of Russia and Turkey). Echoes of the Ages, (1), 192-203. (In Russian).

Blackmore, S. (1999). The meme machine. New York: Oxford University Press.

Borev, Yu. B. (1996). 20th century in legends and anecdotes (Vol. 1). Kharkiv: Folio. (In Russian).

Brodie, R. (1996). Virus of the Mind: The New Science of the Meme. Seattle; Washington: Integral Press.

Bruce, A. (2005). Tiny Revolutions in Russia: Twentieth Century Soviet and Russian History in anecdotes. New York; London: RoutledgeCurzon.

Carlson, K. A. (2011). The impact of humor on memory: Is the humor effect about humor? Humor International Journal of Humor Research, 24(1), 21-41. doi: 10.1515/humr.2011.002

Dainas, A. (2015). Keep Calm and Study Memes. Cleveland: Case Western Reserve University. 
Davison, P. (2009). The Language of Internet Memes. In M. Mandiberg (Ed.), The Social Media Reader (pp. 120-136). New York; London: New York University Press.

Davydov, V. A. (2020). History in the public space: problems and prospects of development. Modern Science: Current Problems of Theory and Practice. Series: Cognition, (3), 97-99. (In Russian).

Demichev, A. A. (2017). The image of Paul I as an «ideal» monarch in the Russian public consciousness of the 18th - early 19th centuries (based on historical anecdotes). Historical and legal problems: a new perspective, (2), 27-36. (In Russian).

Dennett, D. (1991). Consciousness Explained. Boston: Little, Brown a. co., Cop.

Dobrozrakova, G. A. (2019). A historical anecdote from the XVIII century to Dovlatov. In The problems of studying Russian literature of the XVIII century: An interuniversity collection of scientific works dedicated to the memory of Professor, Candidate of Philological Sciences, Natalia Arkadyeuna Buranok (pp. 38-57). Saint Petersburg; Samara: LLC "Scientific and Technical Center". (In Russian).

Douglas, R. (1992). Between the wars 1919-1939: The cartoonists' vision. London: Routledge.

Douglas, R. (1993). Great Nations Still Enchained: The Cartoonists' Vision of Empire 1848-1914. London: Routledge.

Ensink, T., \& Sauer, C. (Eds.). (2003). The art of commemoration fifty years after the Warsaw Uprising. Amsterdam: John Benjamins Publishing Company.

Eremeev, A. E. (1986). A. S. Pushkin and A. I. Herzen (on the question of the artistic functions of philosophical generalization in the form of a historical anecdote in prose of the 1830s). In Problems of Method and Genre (pp. 183-196). Tomsk: National Research Tomsk State University. (In Russian).

Eremeev, A. E. (2012). Historical anecdote as a form of artistic and philosophical generalization in Russian prose of the first third of the 19th century. Omsk Scientific Bulletin, (2), 141-146. (In Russian).

Herzog, R. (2011). Dead Funny: Telling Jokes in Hitler's Germany. Brooklyn; NY: Melville House.

Heylighen, F. (1998). What makes a meme successful? Selection criteria for cultural evolution. In J. Ramaekers (Ed.), 15th International Congress on Cybernetics (pp. 418-423). Namur: Association Internationale de Cybernetique.

Johann, M., \& Bülow, L. (2019). One Does Not Simply Create a Meme: Conditions for the Diffusion of Internet Memes. International Journal of Communication, 13, 1720-1742.

Kessel, M., \& Merziger, P. (Eds.). (2012). The Politics of Humour: Laughter, Inclusion and Exclusion in the Twentieth Century. Toronto; Buffalo; London: University of Toronto Press.

Koshelev, V. A. (1989). Historical functions of a biographical anecdote (Pushkin and Batyushkov). In The Genres of verbal text. Anecdote (p. 30). The Genres of verbal text. Anecdote. (In Russian).

Kurganov, E. (2014). Anecdote as a genre of Russian literature. Moscow: ArsisBooks. (In Russian).

Likhachev, D. S. (1984). Laughter in Ancient Russia. Leningrad: Nauka, Leningrad Branch. (In Russian).

Lotman, Yu. M. (2002). The artistic nature of Russian folk pictures. In Articles on the semiotics of culture and art (pp. 322-339). St. Petersburg: Academic Project. (In Russian).

Lotman, Yu. M. (2010). The semiosphere. St. Petreburg: Art - St. Petersburg. (In Russian).

Malinova, O. Yu. (2019). Memory policy as an area of symbolic policy. Method, (9), 285-312. (In Russian). 
Mezin, S. A. (2002). Anecdotes about Peter the Great as a phenomenon of Russian historiography of the 18th century. Historiographical Collection, (20), 18-54. (In Russian).

Milner, R. M. (2013). Pop Polyvocality: Internet Memes, Public Participation, and the Occupy Wall Street Movement. International Journal of Communication, 7, 2357-2390.

Musiychuk, M. V. (2020). Historical memory in drawings and cartoons of the magazine «Crocodile» (1941-1945) through the prism of wit techniques. The world of science. Sociology, Philology, Cultural Studies, 11(1), 3-11. (In Russian).

Nooney, L., \& Portwood-Stacer, L. (2014). One Does Not Simply: An Introduction to the Special Issue on Internet Memes. Journal of Visual Culture, 13(3), 248-252. doi: 10.1177/1470412914551351

Nora, P. (1999). Problems of memory locations. In France-memory (pp. 17-50). St. Petersburg: Publishing House of the St. Petersburg University. (In Russian).

Panchenko, A. M. (1984). Russian culture on the eve of Peter's reforms. Leningrad: Nauka, Leningrad Branch. (In Russian).

Petrysheva, O. V. (2008). Entertaining stories of Tallemand de Reo: tradition and innovation. Proceedings of the Herzen State Pedagogical University of Russia, (73-1), 347-351. (In Russian).

Piata, A. (2016). When metaphor becomes a joke: Metaphor journeys from political ads to internet memes. Journal of Pragmatics, 106, 39-56. doi: 10.1016/j.pragma.2016.10.003

Propp, V. Ya. (1997). Problems of comedy and laughter. St. Petersburg: Aleteya. (In Russian).

Repina, L. P. (2011). Historical science at the turn of the XX-XXI centuries: social theories and historiographical practice. Moscow: Krug. (In Russian).

Rushkoff, D. (1996). Media Virus!: Hidden Agendas in Popular Culture. New York: Ballantine Books.

Schmidt, S. R. (1994). Effects of humor on sentence memory. Journal of Experimental Psychology: Learning, Memory, and Cognition, 20(4), 953-967. doi: 10.1037/0278-7393.20.4.953

Shaikhutdinova, Z. I., \& Kravchenko, Yu. E. (2017). How does the thematic connection of humor and the remembered image affect the representation of the image in memory? In E. V. Pechenkova \& M. V. Falikman (Eds.), Cognitive Science in Moscow: new Studies. Conference proceedings, Moscow, June 15, 2017 (pp. 403-406). Moscow: KT «Buki-Vedi», Institute of Practical Psychology and Psychoanalysis. (In Russian).

Shifman, L. (2014). Memes in Digital Culture. Massachusetts: MIT Press.

Shomova, S. (2019). The presidential elections of the Russian Federation - 2018 in the mirror of memes: new realities of political communication studies. Polis. Political Studies, (3), 157-173. doi: 10.17976/jpps/2019.03.10 (In Russian).

The artist decided to sue the chocolate factory because of the drawing on the wrapper. (2018). Retrieved from NTV website: https://www.ntv.ru/novosti/1972378/?fb (In Russian).

Twark, J. E. (2017). Approaching History as Cultural Memory Through Humour, Satire, Comics and Graphic Novels. Contemporary European History, 26(1), 175-187. doi: 10.1017/ S0960777316000345

Vereshchatskaya, I. A. (2019). . The image of Catherine II in the urban folklore of the XVIII-first half of the XIX century (on the example of historical anecdotes and rumors). Europe in the Middle Ages and Modern Times: Society. Power. Culture: Materials of the VI All-Russian Scientific Conference of Young Scientists with International participation, Izhevsk, December 04-05, 2018, 215-220. Izhevsk: Izhevsk Institute of Computer Research. (In Russian). 
Vishlenkova, E. A. (2012). "Memory tag": satirical images of the War of 1812. History and Historic Memory, (6), 150-163. (In Russian).

Wilkins, J. S. (1998). What's in a meme? Journal of Memetics - Evolutionary Models of Information Transmission, 2(1), 56-94.

Wöhlert, M. (1995). Der politische Witz in der NS-Zeit am Beispiel ausgesuchter SD-Berichte und Gestapo-Akten [The political joke in the Nazi era using the example of selected SD reports and Gestapo files]. Berlin: Freie Universität. (In German).

Yurchak, A. (2005). Everything Was Forever, Until It Was No More: The Last Soviet Generation. Princeton; Oxford: Princeton University Press.

Yus, F. (2021). Incongruity-resolution humorous strategies in image macro memes. Internet Pragmatics, 4(1), 131-149. doi: 10.1075/ip.00058.yus 